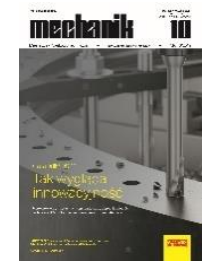

How to cite this article:

Authors: Roksana Zdziarska, Agata Biniek, Daniel Grochała, Mirosław Pajor

Title of article: „Research on the economic efficiency for technological equipment extending of the kinematic chains

on the numerically controlled machines"

Mechanik, No. 10 (2019)

DOI: https://doi.org/10.17814/mechanik.2019.10.80

\title{
Research on the economic efficiency for technological equipment extending of the kinematic chains on the numerically controlled machines
}

\author{
ROKSANA ZDZIARSKA \\ AGATA BINIEK \\ DANIEL GROCHAŁA \\ MIROSŁAW PAJOR *
}

\author{
Inż. Roksana Zdziarska, roksana.zdziarska@zut.edu.pl - Zachodniopomorski Uniwersytet Technologiczny w Szczecinie, Szczecin, Polska \\ Mgr inż. Agata Biniek, agata.biniek@zut.edu.pl, https://orcid.org/0000-0002-8676-5607 - Zachodniopomorski Uniwersytet \\ Technologiczny w Szczecinie, Szczecin, Polska \\ Dr inż. Daniel Grochała, daniel.grochała@zut.edu.pl,https://orcid.org/0000-0003-2553-7739 - Zachodniopomorski Uniwersytet \\ Technologiczny \\ w Szczecinie, Szczecin, Polska \\ Dr hab. inż. Mirosław Pajor, prof. ZUT, miroslaw.pajor@zut.edu.pl, https://orcid.org/0000-0002-7701-385X - Zachodniopomorski \\ Uniwersytet Technologiczny w Szczecinie, Szczecin, Polska
}

The article describes the selection of machining holders included in the so called special machining fixture-tools. The equipment presented in the work is readily used by technologists as a solution extending the kinematic chain of the machine tool. It enables multi-axis machining (from many sides) using one item clamping. This paper presents the calculation of productivity and its growth through the use of special equipment. The research was carried out for medium-volume production, which is quite a difficult area in the design of technologies and the study of production costs. In the technical development of tooling and modeling of its usage costs, it was assumed to maintain the required level of dimensional and shape accuracy with a simultaneous significant reduction of operating costs. As part of the work, a model was also developed for determining the break-even point of investment in special machining tools that are used on triaxial milling machining centers.

KEYWORDS: CNC machines, metal cutting, technological equipment, serial production, production economics

\section{Introduction}

Contemporary manufacturing companies are very often specialized in the production of products in accordance with the standards set by means of industry normatives (IATF ISO 16949 - in the automotive industry, ISO/TC - in aviation and aeronautics, Lloyd's Register regulations - in the maritime industry). This specialization is particularly visible in the area of technology and ensuring the quality standards. It also covers the area of economic efficiency research (controlling) of implemented projects in order to remain competitive compared to other producers [1].

One of the most important limitations of modern technology are the volume of orders and the delivery date. At the same time, due to modern CNC machine tools (multi-axis machining centers), technological concentration is becoming increasingly easier, allowing the shaping of products with complex shapes and high geometric accuracy with a limited number of machining operations. This makes the time of availability of machines and technological devices more efficiently used. The value of the $L_{d o}$ retail operation coefficient per workplace is also increasing:

$$
L_{\mathrm{do}}=\frac{I_{\mathrm{op}}}{I_{\mathrm{p}}}
$$


where: $I_{o p}$ - number of all operations necessary to make one piece, $I_{p}$ - number of workpieces in individual operations.

In the literature, there is such classification of production, in which five basic types are distinguished, i.e. unit, small-series, medium-series, high-volume and mass production [2]. The type of production depends not only on its size, but also on the nature. In order for the production to be as effective as possible, regardless of its type, one should strive to maximize the value of the retail operation coefficient. In the technological processes of typical machine parts in medium-series production, value of the retail operation coefficient is usually in the range of $0.05 \leq L_{d o} \leq 0.2$. For a technologist, this is one of the most difficult areas between unit and mass production, where using very flexible machining centers, it is difficult to limit the number of arrangements and methods of fixing the workpiece so as to ensure free access to all machined surfaces (especially for plates, multi-axis bodies and workpieces). In medium-series production, an alternative to increasing the value of the retail operation coefficient may be the use of special equipment that extends the machine's kinematic chain - this way, it is possible to reduce the total number of machining operations (due to technological concentration) (fig. 1).

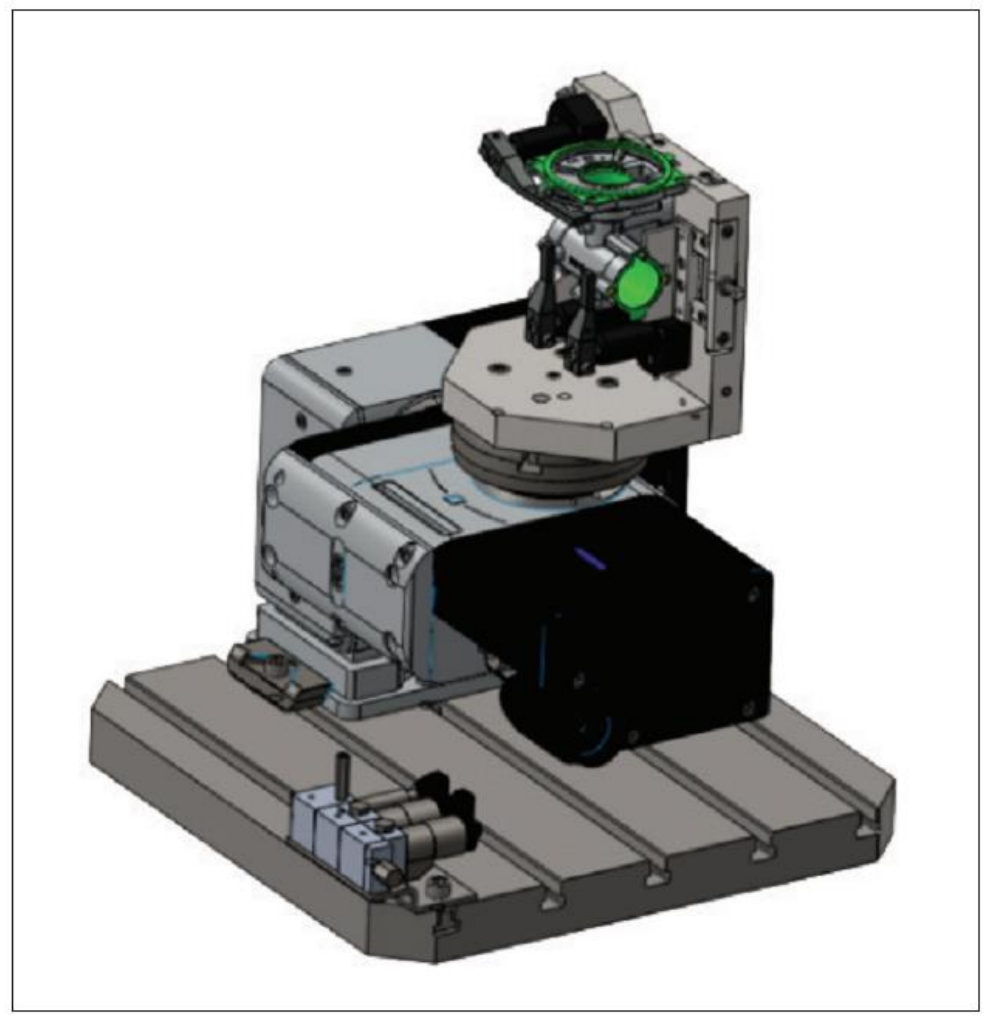

Fig. 1. Tooling for extending the machine tool kinematic chain based on a swivel rotary table and a special machining chuck [3]

The basis for the construction of a special machining device in medium-series production are usually commonly available swivel rotary tables (e.g. pL LEHMANN or PEISELER), which can be easily integrated with the CNC machine tool of any manufacturer. Due to this solution, extension of the machine's kinematic chain is relatively inexpensive. In addition, after using a spindle connection on a rotary table - similar to that in machine tools - it is possible to quickly replace a special machining chuck (also with a hydraulic or pneumatic drive). Such equipment also allows for group machining of workpieces (fig. 2) - in this way, a higher degree of utilization of the machine availability time is ensured, because auxiliary and maintenance times are reduced. 


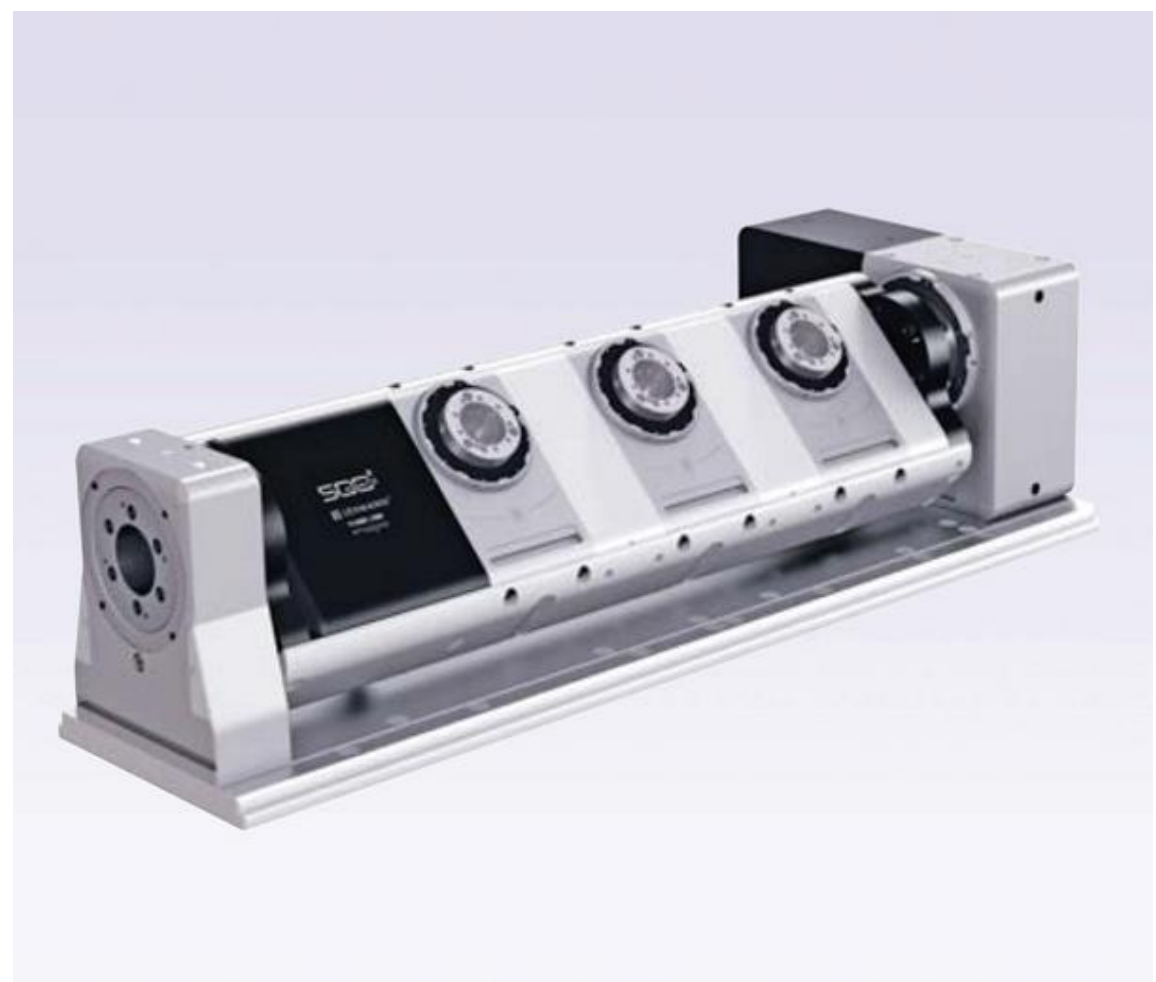

Fig. 2. LEHMANN tilt and rotary table T3-507510, designed for group mean series workpieces [5]

In addition, the mere replacement of the machining chuck in the swivel rotary table, permanently mounted in the machine tool, significantly reduces the time of machine changeovers between successive series of manufactured products [4].

\section{Economic efficiency tests for special tooling}

In the completed research work, medium-series production was looked more closely at the context of the required tooling and the economics of the developed technology [6]. Technological processes in mediumseries production are characterized by greater degree of stabilization of the course compared to unit or smallseries production. This production is also characterized by the presence of an assortment of various types of products - usually of similar dimensions. There is also the repeatability of production of products in series at a set time interval [7].

The research on the profitability of using universal tooling was carried out on the example of the technological process of a multi-axis object (connecting rod) (fig. 3). Prefabricated elements used in the research were pressure cast semi-finished products [8].

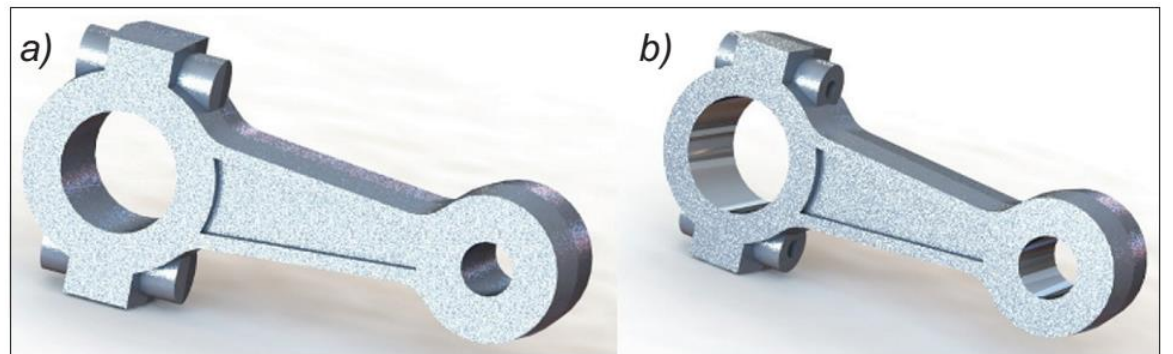

Fig. 3. Part used to test the economic efficiency of special equipment in mean series production: $a$ ) semi-finished product, $b$ ) connecting rod after processing 
The first point of the research plan assumes determination of the labor intensity of two technological operations. The first operation was carried out on a pillar drill equipped with a BISON 6516-M160 jaw chuck [9], in which the cover was drilled, and then threaded in the assembly (connecting rod - cover). The second operation, carried out on the Mikron VCE 500 machining center (also equipped with a BISON jaw chuck), included roughing and finishing reaming of fitted main holes.

The second point of the research plan assumed the use of a special machining tool - tilting and rotary table pL LEHMANN T1507510 with ROEHM RPP-A50 automatic chuck mounted. In this variant, technological machining process was carried out in one set and fixation of the object. The machining tool controlled from the CNC system was responsible for changing the position of the object. In this way, manual drilling and threading operations were eliminated, while the value of the retail operation coefficient $\left(L_{d o}\right)$ was improved.

The main time $\left(t_{g}\right)$ of operations carried out in the first and second variants of the technological process was the same (it was assumed to be used in subsequent operations of the same type of tools working with constant technological parameters), while the auxiliary time $\left(t_{p}\right)$ and the resulting values of the production time were different $\left(t_{w}\right)$ (tab. I).

TABLE I. Time components, determined on the work consumption for the technological operation

\begin{tabular}{|c|c|c|}
\hline $\begin{array}{l}\text { Technological } \\
\text { operation } \\
\text { of unit production } \\
\text { time } t_{\mathrm{j}}\end{array}$ & $\begin{array}{l}\text { 10. Pillar drilling machine } \\
\text { 20. Mikron VCE } 500\end{array}$ & 10. Mikron VCE 500 \\
\hline Czas główny $t_{\mathrm{g}}[\mathrm{s}]$ & 4.88 & 4.88 \\
\hline Czas pomocniczy $t_{\mathrm{p}}[\mathrm{s}]$ & 52 & 35 \\
\hline Czas wytworzenia $t_{\mathrm{w}}[\mathrm{s}]$ & 56.88 & 39.88 \\
\hline
\end{tabular}

TABLE II. Value of means of production and shift cost, calculated in simulation studies

\begin{tabular}{|c|l|c|c|}
\hline \multicolumn{2}{|c|}{$\begin{array}{c}\text { Machine name } \\
\text { + tooling }\end{array}$} & $\begin{array}{c}\text { Cost of production } \\
\text { means [PLN] }\end{array}$ & $\begin{array}{c}\text { Production cost } \\
\text { per shift [PLN] }\end{array}$ \\
\hline 1 & $\begin{array}{l}\text { Pillar drilling machine } \\
\text { + MIKRON VCE 500 }\end{array}$ & 422000 & 123.08 \\
\hline $\begin{array}{l}\text { MIKRON VCE 500 } \\
\text { + Lehmann T1-507510 } \\
\text { + ROEHM RPP-A50 }\end{array}$ & 510400 & 148.87 \\
\hline
\end{tabular}

On the basis of the determined labor consumption and availability time of the machines (adopted in accordance with the VDI 3423 standard) [10], the unit production time was determined, i.e. the time of manufacturing one piece of the product and the time needed to produce a series of five thousand connecting rods (which in the automotive industry is considered as medium-series production). The number of connecting rods produced during one shift is 472 for the first and 673 for the second process variant, respectively. At the same time, the time needed to make a series (5000 pieces) is $84 \mathrm{hrs} 42$ mins for two operations and $59 \mathrm{hrs} 24$ mins for integrated production in one operation.

Only costs resulting from the developed technology and the machine and tooling used were included in the simulation tests.

At the same time, variable components of production costs and general plant costs were omitted [11]. The maximum level of production defectiveness was $5 \%$ for both variants. Value of the machine tool and tooling was determined by individual interview, production costs generated during one work shift were also determined (tab. II). 


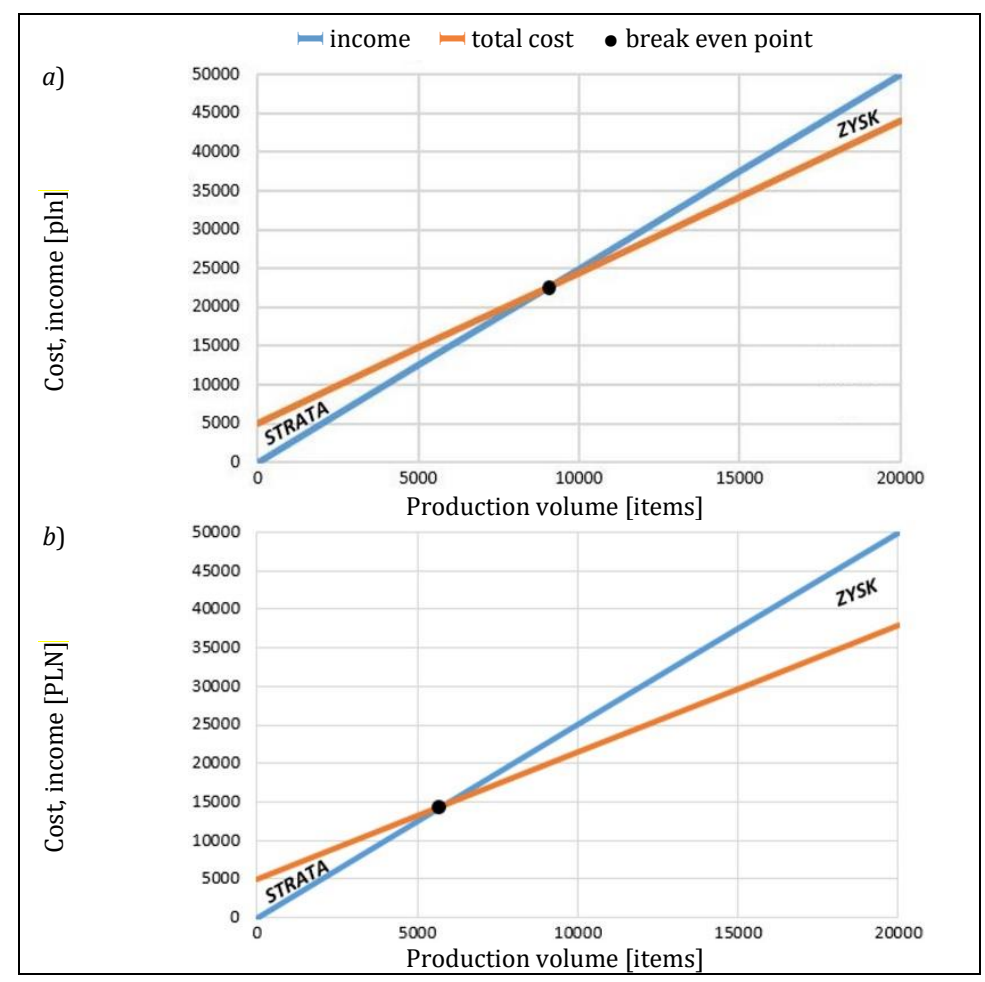

Fig. 4. Graphical representation of the break-even point for the variant I ( $a)$ and II (b)

The unit cost of connecting rod manufacturing was calculated based on the value of the determined unit production time and the time of series production and shift costs. It amounted to PLN 1.95 for the first variant and PLN 1.65 for the second production variant. On this basis, the profitability threshold was determined in both variants (fig. 4), at the same time calculating its economic efficiency $[12,13]$. The calculations show that due to the use of special equipment in the second variant, the machining time of one series was shortened by $30 \%$, which translated into longer machine availability time and thus higher profits. Comparing the breakeven point for both variants, one can notice a significant difference in the number of connecting rods made, at which revenues from sales cover total costs. For the first variant it is 9091, and for the second variant - 5883.

\section{Summary and conclusions}

Modern machine tools offer wide possibilities of integration with modern equipment in order to increase the efficiency of manufacturing processes. This allows to significantly reduce the production costs (however, each time, to perform a productivity analysis and determine the profitability threshold for a given investment is needed), extend the time of availability of machines (which means the possibility of producing more connecting rods), increase revenues and at the same time reduce the time needed to produce a series. In addition, special tooling allows for higher geometric accuracy of products - using one method of setting and fixing the workpiece during machining $[3,14]$.

\section{REFERENCES}

[1] Hamrol A., Zerbst S., Bozek M., Grabowska M., Weber M. "Analysis of the conditions for effective use of numerically controlled machine tools" Advances in Manufacturing. Poznań 2017: 3-12, https://doi.org/10.1007/978-3-319-68619-6_1.

[2] Brzeziński M. „Organizacja produkcji w przedsiębiorstwie”. Warszawa: Difin, 2013.

[3] Abrahamowicz M., Grochała D. „O problemach w projektowaniu specjalnego oprzyrządowania technologicznego do obrabiarek wieloosiowych". Przegląd Mechaniczny. 5 (2015): 40-45.

[4] Honczarenko J. „Elastyczna automatyzacja wytwarzania: Obrabiarki i systemy obróbkowe”. Warszawa: Wydawnictwa Naukowo-Techniczne, 2000.

[5] Jaworski J., Kluz R., Trzepieciński T. „Analiza zużycia narzędzi skrawających podczas obróbki wspornika silnika spalinowego". Mechanik. 3 (2015): 109-115.

[6] www.arcotools.pl/oferta-lehmann (dostęp: 06.07.2019 r.). 
[7] Karpiński T. „Inżynieria produkcji”. Warszawa: Wydawnictwa Naukowo-Techniczne, 2004.

[8] Perzyk M. „Odlewnictwo”. Warszawa: Wydawnictwa Naukowo-Techniczne, 2000.

[9] www.bison-bial.pl/imadla/6516-m160 (dostęp: 06.07.2019 r.).

[10] Standard VDI 3423:2011 Technical availability of machines and production lines. Terms and definitions, determination of time periods and calculation.

[11] Tymowski J. „Technologia budowy maszyn”. Warszawa: Wydawnictwa Naukowo-Techniczne, 1989.

[12] Gabrusewicz W. „Podstawy analizy finansowej”. Warszawa: Polskie Wydawnictwo Ekonomiczne, 2002.

[13] Sawicki K. „Rachunkowość finansowa”. Warszawa: Polskie Wydawnictwo Ekonomiczne, 2005.

[14] Bachtiak-Radka E., Dudzińska S., Grochała D., Berczyński S., Olszak W. „The influence of CNC milling and ball burnishing on shaping complex 3D surfaces". Surface Topography: Metrology and Properties. 5, 1 (2017): 015001. 